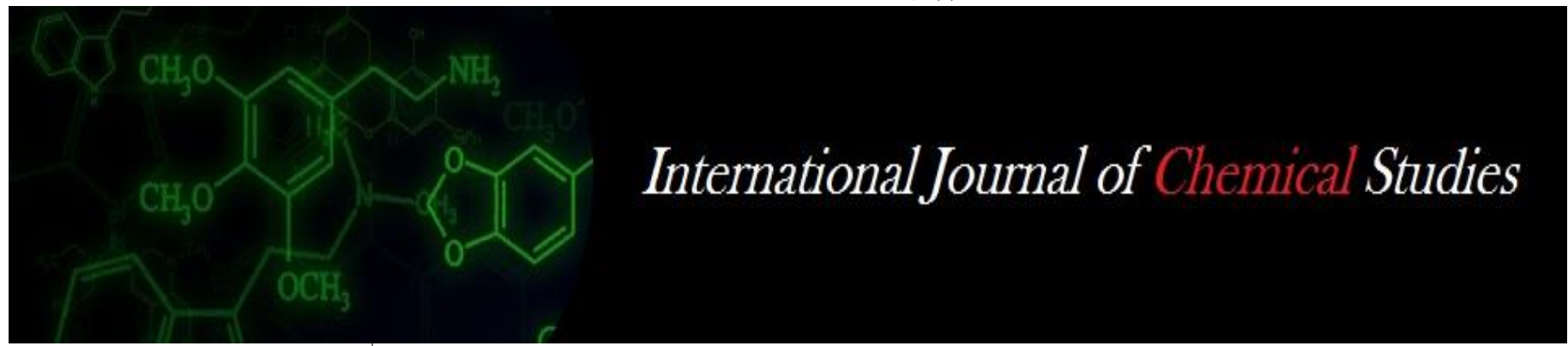

P-ISSN: 2349-8528

E-ISSN: 2321-4902

www.chemijournal.com

IJCS 2021; 9(1): 1373-1378

(C) 2021 IJCS

Received: 08-10-2020

Accepted: 19-11-2020

\section{Farid Ahmad}

Dr. Y. S. Parmer University of

Horticulture and Forestry,

Nauni, Solan, Himachal

Pradesh, India

DK Mehta

Dr. Y. S. Parmer University of

Horticulture and Forestry,

Nauni, Solan, Himachal

Pradesh, India

\section{Rohit Verma}

Dr. Y. S. Parmer University of

Horticulture and Forestry,

Nauni, Solan, Himachal

Pradesh, India
Corresponding Author: Farid Ahmad

Dr. Y. S. Parmer University of Horticulture and Forestry,

Nauni, Solan, Himachal

Pradesh, India

\section{Effect of mulching and planting density on production of sweet banana pepper (Capsicum annuum $\mathbf{L}$.)}

\section{Farid Ahmad, DK Mehta and Rohit Verma}

DOI: https://doi.org/10.22271/chemi.2021.v9.i1t.11413

\section{Abstract}

The present experiment was carried out at Dr Y S Parmer University of Horticulture and Forestry, Nauni, Solan (HP) during Kharif 2019 to study the effect of mulching and planting density on production of Sweet Banana pepper in mid hills of Himachal Pradesh. The experiment was laid out in Randomized Complete Block Design (Factorial) with three replications. The twelve treatment combinations comprised of combination of four different mulches (M) viz., no mulch (M0), pine needle mulch $\left(\mathrm{M}_{1}\right)$ black-plastic mulch $\left(\mathrm{M}_{2}\right)$, silver-black plastic mulch $\left(\mathrm{M}_{3}\right)$ with three planting densities $(\mathrm{P})$ viz., $60 \mathrm{~cm} \times 60 \mathrm{~cm}\left(\mathrm{P}_{1}\right) 60$ $\mathrm{cm} \times 45 \mathrm{~cm}\left(\mathrm{P}_{2}\right)$ and $60 \mathrm{~cm} \times 30 \mathrm{~cm}\left(\mathrm{P}_{3}\right)$. The observations were recorded on growth yield and quality traits, fruit rot incidence (\%), weed count, fresh and dry weight of weeds, soil moisture and temperature. The treatment combination silver-black plastic mulch with plant spacing of $60 \mathrm{~cm} \times 30 \mathrm{~cm}\left(\mathrm{M}_{3} \mathrm{P}_{3}\right)$ was found superior over all other treatment combinations for most of the growth and yield parameters, quality traits, fruit rot incidence and weed control as well as performed well in improving soil moisture and temperature. This treatment combination also had maximum benefit: cost ratio of 4.21:1. Hence silverblack mulch in combination with $60 \mathrm{~cm} \times 30 \mathrm{~cm}$ spacing can be recommended for commercial cultivation of Sweet Banana pepper in North Western Himalayan regions after multi-locational testing.

Keywords: Sweet banana, mulch, planting density, yield

\section{Introduction}

Sweet Banana pepper (capsicum annuum L.) has been named because it bears sweet, banana shape long waxy fruits which matures from yellow to orange and then to crimson red. Banana peppers are especially high in vitamin C, vitamin B6 and folate which all are important in heart health and associated with a reduced risk of cancer. Sweet banana pepper needs welldrained and nutrient rich soil having $\mathrm{pH}$ preferably between 6.0-7.0 (bosland and votava, 2012 ${ }^{[3]}$. Mulching and planting density are the important aspects of production technology of Sweet Banana pepper which possess the capability of increasing the quality of fruit yield. Mulching materials are also known to be beneficial through their contribution in improvement of physical properties of soil and as well as supplying the essential plant nutrients. Plastic mulches are used to suppress weeds and conserve soil moisture. Under plastic mulches, soil properties like soil temperature, moisture content, bulk density, aggregate stability and nutrient availability have been reported to be improved. Many investigators have also given acceptable evidences that most of the mulches, whether organic or inorganic, help in reducing disease prevalence (Agarwal et al. 2003 and Singh et al. 2006) ${ }^{[1,11]}$. Plant density determines the yield and quality of produce in any crop. Optimum plant density can be achieved by establishing appropriate distance both between the rows as well as between the plants within a row. This determines competition among crop plants for minerals, nutrients and also important to facilitate aeration and light penetration into the crop canopy thereby affecting yield and quality of the produce.

\section{Materials and Methods}

The experiment was conducted during Kharif season 2019 at experimental farm of Department of Vegetable Science, Dr. Y.S. Parmar University of Horticulture and Forestry, Nauni, Solan, (HP). 
The soil texture of experimental field is loam to clay loam having $\mathrm{pH}$ ranging from 6.85-7.04. Treatments were combinations of four mulch types, three planting densities. Mulch types (M) were no mulch $\left(\mathrm{M}_{0}\right)$, pine needle mulch $\left(\mathrm{M}_{1}\right)$ black-plastic mulch $\left(\mathrm{M}_{2}\right)$, silver-black plastic mulch $\left(\mathrm{M}_{3}\right)$ with three planting densities $(\mathrm{P})$ viz., $60 \mathrm{~cm} \times 60 \mathrm{~cm}\left(\mathrm{P}_{1}\right)$ $60 \mathrm{~cm} \times 45 \mathrm{~cm}\left(\mathrm{P}_{2}\right)$ and $60 \mathrm{~cm} \times 30 \mathrm{~cm}\left(\mathrm{P}_{3}\right)$. Treatments were arranged in completely randomized block design (factorial) with mulching and planting density. Plastic mulches were laid in the experimental field by hand, one day before transplanting date while the pine needle mulch was applied one month after transplanting. On 17th May, 2019 forty five days old seedlings of Sweet Banana pepper were transplanted by making holes of $5 \mathrm{~cm}$ diameter on the plastic film as the treatments in a plot having size of $1.2 \mathrm{~m} \times 3.6 \mathrm{~m}\left(4.32 \mathrm{~m}^{2}\right)$ and the treatments were replicated three times. The data were recorded on different growth and yield characters and subjected to statistical analysis using Analysis of Variance (ANOVA) technique.

\section{Results and Discussion \\ Main effect of mulch on growth, yield and quality characters}

Data presented in Table1 revealed that mulching significantly influenced growth and yield characters of sweet banana pepper. The days to 50 per cent flowering and days to first picking were not significantly influenced by mulching as it may be due to extended vegetative growth of the plants obtained with mulching. While early flowering and less number of days taken to first picking were recorded in plots without mulching. Among different mulching treatments maximum average plant height $(72.78 \mathrm{~cm})$, plant spread (43.62), number of leaves $(373.82 \mathrm{~cm})$ per plant, leaf size $(56.93 \mathrm{~cm} 2)$, fruit weight $(38.56 \mathrm{~g})$, fruit length $(13.55 \mathrm{~cm})$, fruit diameter $(30.93 \mathrm{~mm})$ were recorded in silver-black plastic mulch treated plots followed by back plastic mulch. This might be black plastic mulch which created microenvironment, i.e. optimum moisture, optimum nutrient supply and optimum soil temperature, which resulted in better plant performance. It also helps to increase microbial activity for optimum nutrient/water uptake from the soil Ogutu (2006) [8].

Silver black plastic mulch performed better with maximum number of fruits (45.71) per plant, maximum fruit yield (1511.34 g, $26.01 \mathrm{~kg}$ and $481.50 \mathrm{q}$ respectively) per plant, per plot and per hectare. This could be due to improving the availability of applied nutrients through conservation of soil moisture and smothering of weeds by mulches. The results in the present study are in agreement with the findings of Lodhi et al (2019) ${ }^{[6]}$ in bell pepper. Whereas, TSS and ascorbic acid contents were not significantly influenced by mulching possibly because it is a varietal character and is least influenced by environmental factors as well as by cultural practices. The results of the present study are in agreement with the findings of Maida et al. (2019) ${ }^{[7]}$ in chili. The net return from the mulched treatments was much higher than without mulch as shown in Table 1 . The maximum net return (1348839Rs/ha) was recorded with silver black plastic mulch followed by black plastic mulch (933864 Rs/ha) and minimum (211259 Rs/ha) net return was obtained in without mulching treatments.

Table 1: Effects of mulching and planting density on growth, yield and quality characters

\begin{tabular}{|c|c|c|c|c|c|c|c|c|c|c|c|c|c|c|c|}
\hline \multirow[b]{2}{*}{ Treatments } & \multicolumn{15}{|c|}{ Growth, yield and quality characters } \\
\hline & $\begin{array}{c}\text { Days to } \\
50 \% \\
\text { flowering }\end{array}$ & $\begin{array}{c}\text { Days to } \\
\text { first } \\
\text { picking }\end{array}$ & $\begin{array}{c}\text { Plant } \\
\text { height } \\
\text { (cm) }\end{array}$ & $\begin{array}{c}\text { Plant } \\
\text { spread } \\
(\mathrm{cm})\end{array}$ & $\begin{array}{c}\text { No. of } \\
\text { leaves } \\
\text { per plant }\end{array}$ & $\begin{array}{c}\text { Leaf } \\
\text { size } \\
\left(\mathrm{cm}^{2}\right)\end{array}$ & $\begin{array}{c}\text { Fruit } \\
\text { weight } \\
\text { (g) }\end{array}$ & $\begin{array}{c}\text { Fruit } \\
\text { length } \\
(\mathbf{c m})\end{array}$ & $\begin{array}{c}\text { Fruit } \\
\text { Diameter } \\
(\mathbf{m m})\end{array}$ & $\begin{array}{c}\text { No. of } \\
\text { fruits } \\
\text { per } \\
\text { plant }\end{array}$ & $\begin{array}{c}\text { Fruit } \\
\text { yield per } \\
\text { plant (g) }\end{array}$ & $\begin{array}{c}\text { Fruit } \\
\text { yield per } \\
\text { plot (kg) }\end{array}$ & $\begin{array}{c}\text { Fruit } \\
\text { yield per } \\
\text { heater }(\mathbf{q})\end{array}$ & TSS & $\begin{array}{l}\text { Ascorbic acid } \\
\text { contents } \\
(\mathrm{mg} / 100 \mathrm{~g})\end{array}$ \\
\hline \multicolumn{16}{|c|}{ Main effect of mulch } \\
\hline $\mathrm{M}_{0}$ & .33 & .00 & 62.48 & 39.53 & 167.28 & 46.41 & 34.71 & 11.63 & 28.39 & 0.64 & 88.30 & 4.56 & 69.56 & 5.07 & 131.00 \\
\hline $\mathrm{M}_{1}$ & 36.22 & 5.88 & 59.17 & 36.84 & 145.68 & 44.07 & 32.57 & 10.18 & 27.93 & 27.09 & 747.10 & 12.46 & 230.58 & 5.37 & 128.22 \\
\hline $\mathrm{M}_{2}$ & & 8 & 68.73 & 41.04 & .42 & 53.24 & 37.67 & & & .44 & 75 & & .02 & 5.07 & \\
\hline $\mathrm{M}_{3}$ & 41.22 & 73.11 & 72.78 & 43.62 & 373.82 & 56.93 & 38.56 & 13.55 & 30.93 & 45.71 & 1511.34 & 26.01 & 481.50 & 5.02 & 4.55 \\
\hline $\mathrm{CD}_{\text {at } 5}$ & 1. & 1.48 & 3.02 & 3.02 & 21.15 & 2.85 & 1.81 & 0.52 & 1.88 & 2.89 & 87 & 157 & 29.11 & NS & ST \\
\hline \multicolumn{16}{|c|}{ Main effect of planting density } \\
\hline $\mathrm{P}_{1}$ & 91 & 7.50 & 63.61 & 42.26 & 158.17 & 51.86 & 36.13 & 12.88 & 30.60 & 40.90 & \begin{tabular}{|l|}
1216.99 \\
\end{tabular} & 14.60 & 270.32 & 5.55 & 136.08 \\
\hline $\mathrm{P}_{2}$ & .83 & .50 & 64.09 & 40.61 & 223.46 & 50.03 & 37.48 & 11.91 & 28.68 & 36.09 & \begin{tabular}{|l|}
1186.81 \\
\end{tabular} & 18.99 & 351.49 & 5.12 & 128.25 \\
\hline $\mathrm{P}_{3}$ & 8 & & 69.69 & 37. & & 48.59 & 34.02 & & 27 & 32.42 & & 12 & 427.95 & 4.72 & 133.67 \\
\hline $\mathrm{CD}_{\text {at } 5 \%}$ & 1.66 & 1.28 & 2.61 & 2.61 & 18.32 & 2.46 & 1.56 & 0.45 & 1.63 & 2.50 & 74.11 & 1.36 & 25.21 & 0.49 & NS \\
\hline \multicolumn{16}{|c|}{ Interaction $\mathbf{M} \times \mathbf{P}$} \\
\hline $\mathrm{M}_{0} \times \mathrm{P}_{1}$ & 29.00 & 66 & .17 & .20 & 07 & 50.06 & 37.53 & 11.70 & 30.14 & 5.47 & 63 & 12.18 & 37 & 5.63 & 3.67 \\
\hline $\mathrm{M}_{0} \times \mathrm{P}_{2}$ & 33.00 & 64.33 & 62.30 & 40.66 & 131.70 & 48.13 & 35.13 & 10.97 & 27.89 & 32.80 & \begin{tabular}{|l|}
1011.68 \\
\end{tabular} & 16.19 & 299.62 & 4.83 & 129.67 \\
\hline $\mathrm{M}_{0} \times \mathrm{P}_{3}$ & 32.00 & 66.00 & 64.00 & 37.73 & 138.07 & 41.03 & 31.47 & 12.21 & 27.14 & 23.67 & 638.61 & 15.33 & 283.69 & 4.73 & 119.67 \\
\hline $\mathrm{M}_{1} \times \mathrm{P}_{1}$ & 34.00 & 65.00 & 57.00 & 41.13 & 154.13 & 47.35 & 31.00 & 10.96 & 28.90 & 31.27 & 786.56 & 9.44 & 174.71 & $5.60 \mid$ & 121.67 \\
\hline $\mathrm{M}_{1} \times \mathrm{P}_{2}$ & 66 & & 59.07 & 3566 & 142.04 & 41.85 & 36.40 & 10.10 & 27.14 & 27.10 & 872.56 & 13.96 & 258.42 & 5.40 & 120.67 \\
\hline $\mathrm{M} \times \mathrm{P}$ & 3000 & & 61.47 & 3273 & 140.87 & 43.00 & 30.33 & 0 & 27.76 & 22.90 & 582.17 & 13.97 & 258.63 & 5.10 & 142.33 \\
\hline $\mathrm{M}_{2} \times \mathrm{P}_{1}$ & 66 & 33 & 6 & 16 & 286.50 & 54.03 & 36.73 & 14.23 & 30.09 & 47.53 & \begin{tabular}{|l|}
1434.33 \\
\end{tabular} & 17.21 & 318.59 & 5.43 & 132.33 \\
\hline $\mathrm{M}_{2} \times \mathrm{P}_{2}$ & 43.66 & 75.00 & 66.40 & 42.13 & 267.57 & 54.32 & 39.53 & 13.27 & 28.47 & 42.87 & \begin{tabular}{|l|}
1464.51 \\
\end{tabular} & 23.43 & 433.73 & $5.07 \mid$ & 136.00 \\
\hline $\mathrm{M}_{2} \times \mathrm{P}_{3}$ & 43.66 & 77.33 & 72.26 & 37.53 & 218.20 & 51.36 & 36.73 & 13.00 & 29.90 & 36.93 & \begin{tabular}{|l|}
1129.42 \\
\end{tabular} & 27.10 & 501.74 & 4.70 & 142.33 \\
\hline $\mathrm{M} 3 \times \mathrm{P}_{1}$ & 39.00 & 71.00 & 71.74 & 44.27 & 360.00 & 55.98 & 39.27 & 14.65 & 33.27 & 49.33 & \begin{tabular}{|l|}
1632.43 \\
\end{tabular} & 19.59 & 362.59 & 5.53 & 146.67 \\
\hline $\mathrm{M}_{3} \times \mathrm{P}_{2}$ & 39.00 & 72.33 & 68.60 & 44.00 & 352.53 & 55.81 & 38.87 & 13.31 & 31.24 & 41.60 & \begin{tabular}{|l|}
1398.51 \\
\end{tabular} & 22.38 & 414.18 & 5.20 & 126.67 \\
\hline $\mathrm{M}_{3} \times \mathrm{P}_{3}$ & 45.66 & 67.00 & 78.03 & 42.60 & 408.93 & 58.98 & 37.53 & 13.69 & 28.27 & 46.20 & 1503.08 & 36.7 & 667.73 & 4.33 & 130.33 \\
\hline $\mathrm{CD}_{\text {at } 5 \%}$ & NS & NS & 5.13 & NS & 36.64 & 4.93 & 3.13 & 0.90 & NS & 5.00 & 148.21 & 2.72 & 25.21 & \begin{tabular}{|l|} 
NS \\
\end{tabular} & NS \\
\hline
\end{tabular}

\section{Main effect of mulch on diseases and weed characters}

Data presented in Table 2 showed that diseases and weed attributes were significantly influenced by mulching. The average fruit rot incidence was minimum in silver-black plastic mulched plots $(4.73 \%)$, whereas maximum average fruit rot incidence was recorded in without mulching treatments $(11.63 \%)$ Plastic mulching also reduces disease by inhibiting the creation of bridge of dead tissues between the soil and the plants. It also reduces weed population which leads to the starvation of fungus by eradication of weed hosts. 
The results of the present study are in agreement with the findings of Vawdrey et al. (2004) ${ }^{[14]}$.

Similarly, less number of weeds per $\mathrm{m} 2$, average fresh and dry weight of weeds $\mathrm{g} / \mathrm{m} 2$ was minimum in plastic mulch treated plots $(325.44,412.47 \mathrm{~g} / \mathrm{m} 2$ and $113.20 \mathrm{~g} / \mathrm{m} 2$ respectively), while maximum number of weeds per $\mathrm{m} 2$, fresh and dry weigh of weeds $\mathrm{g} / \mathrm{m} 2$ was recorded in without mulch treatments $(1152.11,1184.10 \mathrm{~g} / \mathrm{m} 2$ and $284.28 \mathrm{~g} / \mathrm{m} 2$ respectively).Plastic mulching materials were found to be better for weed control efficiency, among all mulching treatments silver black plastic mulch recorded maximum $(63.68 \%)$ weed control efficiency followed by black plastic mulch whereas minimum $(27.12 \%)$ weed control efficiency was recorded in unmulched treated plots. This may be due to the fact that plastic mulch inhibits the photosynthetic activity of the weeds, limit weeds growth and development, whereas without mulching enhanced photosynthetic activity and weeds performed well. Mulches are effective in weed control by improving the crop growing environment, plastic mulches create partial anaerobic conditions thus finally resulting in very low weed population which resulted in increased growth and fruit yield. This is also evident from the data on weed count, fresh and dry weight of weeds. Ashrafuzzaman et al. $(2011)^{[2]}$.

Table 2: Effects of mulching and planting density on diseases and weeds Characters

\begin{tabular}{|c|c|c|c|c|c|}
\hline \multirow[b]{2}{*}{ Treatments } & \multicolumn{5}{|c|}{ Diseases and weeds Characters } \\
\hline & $\begin{array}{c}\text { Incidence of fruit } \\
\operatorname{rot}(\%)\end{array}$ & $\begin{array}{c}\text { Weed count per } \\
\mathbf{m}^{2}\end{array}$ & $\begin{array}{c}\text { Fresh dry weight of weeds } \\
\text { (g) }\end{array}$ & $\begin{array}{c}\text { Dry weightof weeds } \\
(\mathrm{g})\end{array}$ & $\begin{array}{c}\text { Weed control efficiency } \\
(\%)\end{array}$ \\
\hline \multicolumn{6}{|c|}{ Main effect of mulch } \\
\hline $\mathrm{M}_{0}$ & $11.63(3.54)$ & 1152.11 & 1184.10 & 284.28 & - \\
\hline $\mathrm{M}_{1}$ & $9.10(3.18)$ & 666.89 & 724.67 & 211.39 & $27.12(31.32)$ \\
\hline $\mathrm{M}_{2}$ & $4.92(2.43)$ & 344.11 & 426.66 & 120.05 & $57.70(49.41)$ \\
\hline $\mathrm{M}_{3}$ & $4.73(2.39)$ & 325.44 & 412.47 & 113.20 & $63.68(52.94)$ \\
\hline $\mathrm{CD}_{\text {at } 5 \%}$ & $11.63(3.54)$ & 2.82 & 4.39 & 3.93 & 1.10 \\
\hline \multicolumn{6}{|c|}{ Main effect of planting density } \\
\hline $\mathrm{P}_{1}$ & $6.64(2.72)$ & 626.92 & 689.62 & 184.61 & $36.07(32.81)$ \\
\hline $\mathrm{P}_{2}$ & $7.44(2.86)$ & 625.66 & 683.27 & 179.59 & $38.22(34.10)$ \\
\hline $\mathrm{P}_{3}$ & $8.71(3.06)$ & 613.83 & 688.03 & 182.49 & $37.08(33.34)$ \\
\hline $\mathrm{CD}$ at $5 \%$ & 0.10 & 7.22 & 3.80 & 3.41 & 0.96 \\
\hline \multicolumn{6}{|c|}{ Interaction $\mathrm{M} \times \mathrm{P}$} \\
\hline $\mathrm{M}_{0} \times \mathrm{P}_{1}$ & $9.53(3.24)$ & 1167.66 & 1193.11 & 288.79 & \\
\hline $\mathrm{M}_{0} \times \mathrm{P}_{2}$ & $11.01(3.46)$ & 1166.66 & 1175.48 & 278.73 & \\
\hline $\mathrm{M}_{0} \times \mathrm{P}_{3}$ & $14.34(3.91)$ & 1122.00 & 1183.70 & 285.33 & \\
\hline $\mathrm{M}_{1} \times \mathrm{P}_{1}$ & $8.80(3.13)$ & 668.33 & 718.13 & 208.37 & $27.82(31.80)$ \\
\hline $\mathrm{M}_{1} \times \mathrm{P}_{2}$ & $8.90(3.14)$ & 650.00 & 720.76 & 208.70 & $29.85(33.07)$ \\
\hline $\mathrm{M}_{1} \times \mathrm{P}_{3}$ & $9.61(3.25)$ & 682.33 & 735.13 & 217.11 & $23.68(29.10)$ \\
\hline $\mathrm{M}_{2} \times \mathrm{P}_{1}$ & $4.36(2.30)$ & 344.33 & 428.42 & 124.83 & $56.79(48.89)$ \\
\hline $\mathrm{M}_{2} \times \mathrm{P}_{2}$ & $4.64(2.37)$ & 356.33 & 425.09 & 116.88 & $57.34(49.21)$ \\
\hline $\mathrm{M}_{2} \times \mathrm{P}_{3}$ & $5.77(2.60)$ & 331.66 & 426.48 & 118.44 & $58.96(50.14)$ \\
\hline $\mathrm{M} 3 \times \mathrm{P}_{1}$ & $3.86(2.20)$ & 327.33 & 418.82 & 116.46 & $59.67(50.55)$ \\
\hline $\mathrm{M}_{3} \times \mathrm{P}_{2}$ & $5.19(2.48)$ & 329.66 & 411.77 & 114.06 & $65.68(54.14)$ \\
\hline $\mathrm{M}_{3} \times \mathrm{P}_{3}$ & $5.15(2.48)$ & 319.33 & 406.83 & 182.49 & $65.69(54.13)$ \\
\hline $\mathrm{CD}_{\text {at }} 5 \%$ & 0.21 & 7.22 & 7.60 & 6.28 & 1.92 \\
\hline
\end{tabular}

Main effect of mulch on soil moisture and temperature

Data presented in Fig 1 revealed that mulching materials showed variation in soil temperature, among all mulch treatments black plastic mulch showed great variation in soil temperature form $25.97^{\circ} \mathrm{C}-28.55^{\circ} \mathrm{C}$. However, without mulching, temperature range was comparatively lower $21.77^{\circ} \mathrm{C}-24.11^{\circ} \mathrm{C}$. Black plastic mulches are more effective in increasing soil temperature due to a greater net radiation under the mulch as compared to bare soil. Streak et al. (1994) ${ }^{[12]}$. Black plastic mulch recorded higher soil moisture $22.28 \%$ - $27.97 \%$ followed by silver black plastic mulch. The black polythene mulch reduces the evaporation rate and retains soil moisture similar trends were also reported by Ravinder et al. $1997^{[10]}$. 


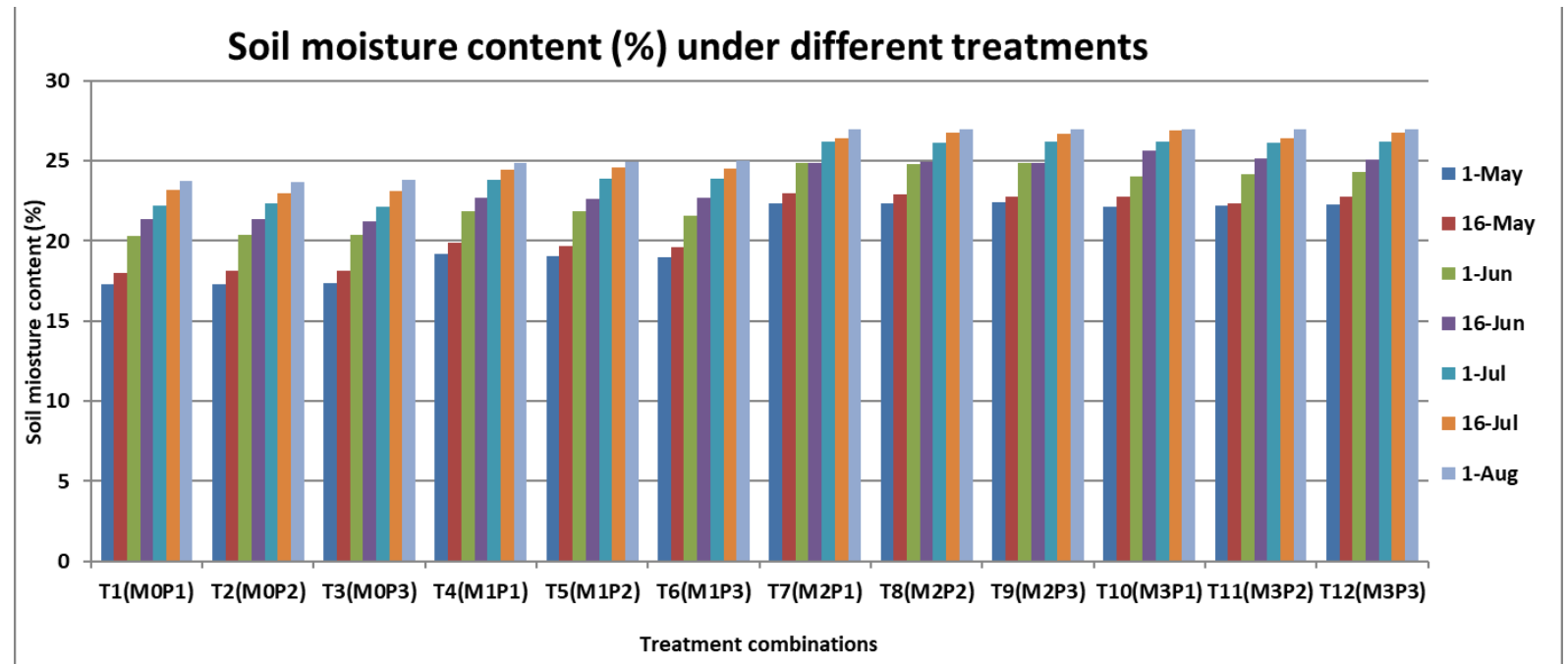

Fig 1: Soil moisture content under different treatments recorded during the cropping period at 0-30 cm depth

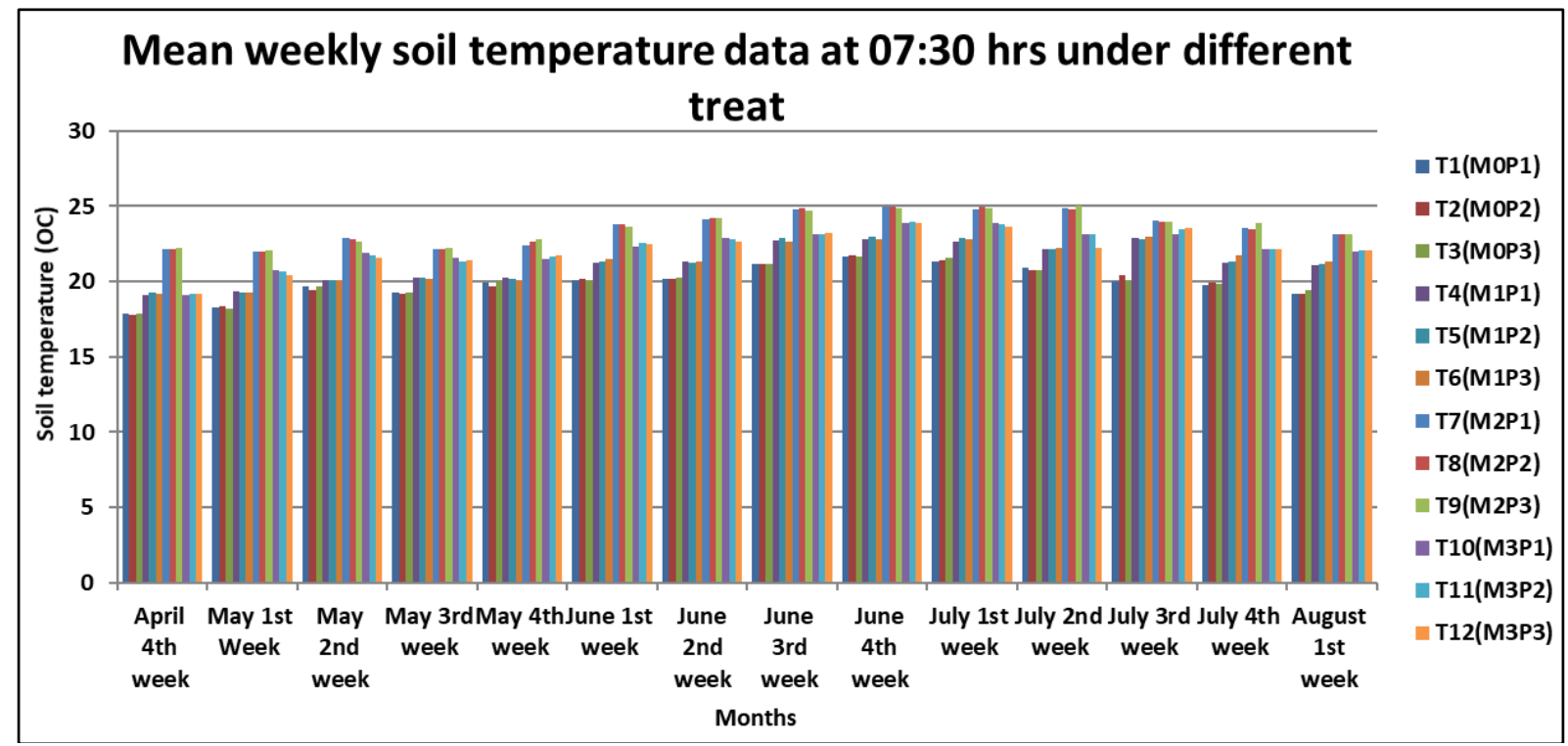

Fig 2: Mean weekly maximum and minimum soil temperature at $10-15 \mathrm{~cm}$ soil depth under different mulch materials and planting density was recorded at 7.30 hours

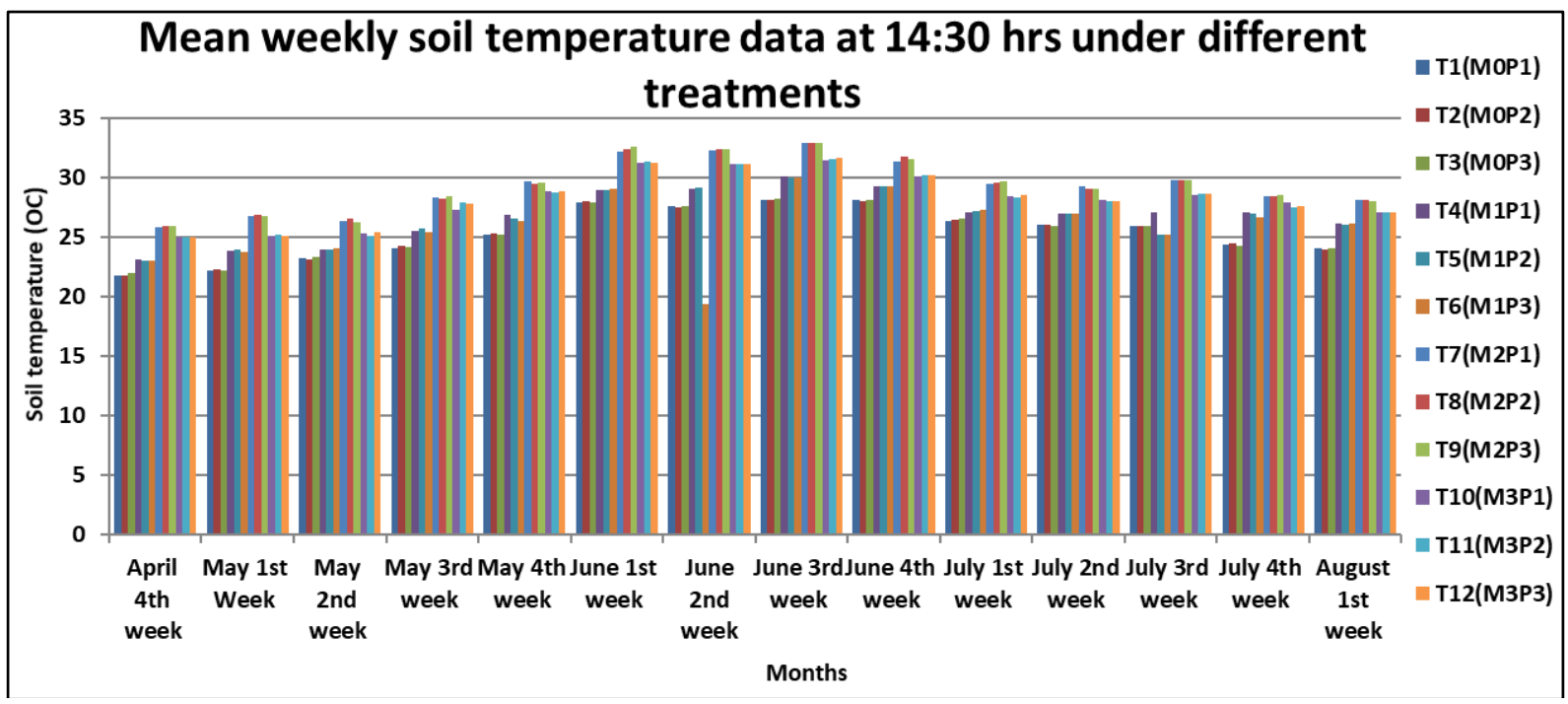

Fig 3: Mean weekly maximum and minimum soil temperature at $10-15 \mathrm{~cm}$ soil depth under different mulch materials and planting density was recorded at 14.30 hours. 


\section{Main effect of planting density on growth, yield and quality characters}

Data presented in Table 1 revealed that planting density led to improved growth, yield and quality traits. The flowering was advanced by 5 days in planting density of $60 \mathrm{~cm} \times 60 \mathrm{~cm}\left(\mathrm{P}_{1}\right)$ resulting in an early fruit harvesting. Among all planting densities maximum plant height $(69.69 \mathrm{~cm})$ was recorded in $60 \mathrm{~cm} \times 30 \mathrm{~cm}\left(\mathrm{P}_{3}\right)$, while maximum $(42.26 \mathrm{~cm})$ plant spread, number of leaves per plant $(258.17)$, leaf size, $\left(51.86 \mathrm{~cm}^{2}\right)$ fruit weight $(37.48 \mathrm{~g})$, fruit length $(12.88 \mathrm{~cm})$, fruit diameter $(30.60 \mathrm{~mm})$, number of fruits (40.90) and fruit yield per plant $(1216.99 \mathrm{~kg})$ were recorded at a spacing of $60 \mathrm{~cm} \times 60 \mathrm{~cm}\left(\mathrm{P}_{1}\right)$ this might be due to less competition between and within the plants for nutrients, sunlight and water resulting in better growth and development of the fruits, similar trends were also reported by Islam et al. (2011) ${ }^{[4]}$ in bell pepper. Spacing of $60 \mathrm{~cm} \times 60 \mathrm{~cm}\left(\mathrm{P}_{1}\right)$ was found to be better treatment for fruit yield per plot and per hectare. Maximum fruit yield per plot and per hectare $(23.12 \mathrm{~kg}$ and 427.95 , q respectively) was recorded at a spacing of $60 \mathrm{~cm} \times 30 \mathrm{~cm}\left(\mathrm{P}_{3}\right)$. This may be due to more plant population per unit area resulting in increased in fruit yield per plot and per hectare. Yield of fruits per unit area is inversely related to the plant spacing i.e., closest the plant spacing higher the yield of fruits per unit area (Russo 2003) [9]. While with respect to TSS and ascorbic acid contents planting density had non-significant influence.

\section{Main effect of planting density on diseases and weed characters}

Data presented in Table 2 showed that main effects of planting density showed significant effect on fruit rot incidence. Minimum fruit rot incidence $(6.64 \%)$ was recorded at widest spacing of $60 \mathrm{~cm} \times 60 \mathrm{~cm}\left(\mathrm{P}_{1}\right)$. whereas maximum fruit rot incidence $(8.71 \%)$ was recorded at the closet spacing of $60 \mathrm{~cm} \times 30 \mathrm{~cm}\left(\mathrm{P}_{3}\right)$. This could be due to the fact that at higher population per unit area there is more relative humidity within plants leading to more incidence of disease Similar results were also reported by Verma et al. (2016) ${ }^{[13]}$ in bell pepper.

Minimum number (613.83) of weeds $\mathrm{m}^{2}$ was recorded in closest spacing of $60 \mathrm{~cm} \times 30 \mathrm{~cm}\left(\mathrm{P}_{3}\right)$ whereas maximum number of weeds (626.92) was recorded in widest spacing of $60 \mathrm{~cm} \times 60 \mathrm{~cm}\left(\mathrm{P}_{1}\right)$. While, minimum fresh and dry weight (683.27 $\mathrm{g}$ and $179.59 \mathrm{~g}$ respectively) of weeds with maximum weed control efficiency was recorded at closest spacing of 60 $\mathrm{cm} \times 45 \mathrm{~cm}\left(\mathrm{P}_{2}\right)$. High density plant canopy might also have restricted the light to reach the weeds and hence there is reduced photosynthesis by the weed plants resulting into shortage of carbohydrates and this could be another reason for reduced growth and development of weeds in those plots (Kumar 2009) ${ }^{[5]}$.

\section{Interaction effects of mulching and planting density on growth, yield and quality characters}

A perusal of data presented in Table 1 revealed that maximum plant height $(78.03 \mathrm{~cm})$, more number of fruits per plant (408.93), maximum leaf size $\left(58.98 \mathrm{~cm}^{2}\right)$, maximum fruit yield per plot and per hectare $(36.07 \mathrm{~kg}$ and $667.73 \mathrm{q}$ respectively) were recorded when the treatment combination of $\mathrm{M}_{3} \mathrm{P}_{3}$ (silver-black plastic mulch with a spacing of $60 \mathrm{~cm} \times$ $30 \mathrm{~cm}$ ) were used. Which may be due to the interaction of benefits of silver-black plastic mulch (higher photo synthetically active radiation (PAR) being reflected back into plant canopy, better weed control, optimum root zone temperature and better nutrient availability to the plants, optimum spacing led to better growth of plants because of less inter and intra plant competition for nutrients, water and light. While, fruit length, number of fruits per plant and fruit yield per plant were maximum $(14.65 \mathrm{~cm}, 49.33$ and $1632.43 \mathrm{~g}$ respectively) when treatment combination of $\mathrm{M}_{3} \mathrm{P}_{1}$ (silverblack plastic mulch with $60 \mathrm{~cm} \times 60 \mathrm{~cm}$ spacing) were used, however days to 50 per cent flowering, days to first picking, plant spread, fruit diameter, TSS and ascorbic acid contents were recorded non-significant due to interaction effect of mulching and planting density.

Interaction effects of mulching and planting density on diseases and weed characters

Data presented in Table 2 showed that minimum incidence of fruit trot $(3.86 \%)$ was recorded when the treatment combination of $\mathrm{M}_{3} \mathrm{P}_{1}$ (silver-black plastic mulch with $60 \mathrm{~cm} \times$ $60 \mathrm{~cm}$ spacing) were used, while weed number was minimum (319.33) with the treatment combination of $\mathrm{M}_{2} \mathrm{P}_{3}$ (silver-black plastic mulch with of $60 \mathrm{~cm} \times 30 \mathrm{~cm}$ spacing). In case of fresh weight, dry weight and weed control efficiency the treatment combination of $\mathrm{M}_{3} \mathrm{P}_{3}$ (silver-black plastic mulch with $60 \mathrm{~cm} \times 30 \mathrm{~cm}$ spacing) was found to perform better.

\section{Summary}

The experiment was conducted during Kharif season 2019 at experimental farm of Department of Vegetable Science, Dr. Y.S. Parmar University of Horticulture and Forestry, Nauni, Solan, (HP).to evaluate the effect of mulching and planting density on production of sweet banana pepper (Capsicum annum L.). Four different mulch materials were no mulch $\left(\mathrm{M}_{0}\right)$, pine needle mulch $\left(\mathrm{M}_{1}\right)$ black-plastic mulch $\left(\mathrm{M}_{2}\right)$, silver-black plastic mulch $\left(\mathrm{M}_{3}\right)$ with three planting densities (P) viz., $60 \mathrm{~cm} \times 60 \mathrm{~cm}\left(\mathrm{P}_{1}\right) 60 \mathrm{~cm} \times 45 \mathrm{~cm}\left(\mathrm{P}_{2}\right)$ and $60 \mathrm{~cm} \times 30$ $\mathrm{cm}\left(\mathrm{P}_{3}\right)$. Were tested in a factorial randomized block design. The maximum growth, flowering, yield and yield attributing characters, quality trait, weed number, fresh and dry weight of weeds, maximum weed control efficiency, soil moisture and temperature were recorded with silver-black plastic mulch, due to soil temperature regulation and soil moisture conservation followed by black mulch and poor plant performance in without mulch, however no mulch also fetched an appreciable profit as compared to pine needle mulch due to high $\mathrm{C}: \mathrm{N}$ ratio.

\section{References}

1. Agarwal A, Gupta S, Ahmed Z. Influence of plant densities on productivity of bell pepper (Capsicum anпиит L.) under greenhouse in high altitude cold desert of Ladakh. International Symposium on Medicinal and Nutraceutical Plants 2007;756:309-14.

2. Ashrafuzzaman M, Halim MA, Ismail MZ, Shahidullah SM, Hossain A. Effect of plastic mulch on growth and yield of Chilli (Capsicum annuum L).Brazilian Archives of Biology and Technology 2011;54:321-30.

3. Bosland PW, Votava EJ. Peppers: Vegetable and Spice Capsicums. CAB International, Oxfordshire, UK 2012. 243p.

4. Islam M, Saha S, Akand H, Rahim A. Effect of spacing on the growth and yield of sweet pepper (Capsicum annuиm L.).Journal of Central European Agriculture 2011;12:328-35.

5. Kumar NS. Effect of plant density and weed management practices on production potential of groundnut (Arachishypogaea L.). Indian Journal of Agricultural Research 2009;43:1-15. 
6. Lodhi Y, Chakravorty S, Prasad BVG, Chandrakar S. Influence of nutrients and mulching on fruiting and fruit characteristics of bell pepper (Capsicum annum L.). The Pharma Innovation Journal 2019;8:791-94

7. Maida P, Bisen BP, Diwan G. Effect of plastic mulch on growth and yield of chilli (Capsicum annuum L.).International Journal of Current Microbiology and Applied Sciences 2019;8:2056-62.

8. Ogutu M. Effects of colored plastic mulches on bell pepper yield and fruit characteristics. Hort Science 2006;41:1075-76.

9. Russo VM. Planting date and plant density affect yield of pungent and non-pungent jalapeno peppers. Hort Science 2003;38:520-23.

10. Ravinder K, Srivastava BK, Kumar R. Effect of different mulch materials on the soil temperature and moisture in winter tomato. Crop Research 1997;14:137-41.

11. Singh IS, Awasthi OP, Meena SR. Influence of mulch on hydrothermal regimes, leaf and soil nutrients concentrations, growth and yield of brinjal grown under ecosystem. Agropedology 2006;16:112-16.

12. Streak NA, Schneider FM, Buriol GA. Modificacoes fisicas causadas pelo mulching. Revista Brasileira de Agrometeorologia 1994;2:131-42.

13. Verma R, Mehta DK, Thakur KS, Prasad H, Lal M. Effect of mulching and planting geometry on seed production of bell pepper (Capsicum annuum L.) in midhills of Himachal Pradesh. Journal of Bio-resources and Stress Management 2016;7:1146-51.

14. Vawdrey LL, Grice KE, Peterson RA. Diversity and management of Phytopthora in Southeast Asia. ACIAR Monograph 2004;114:167-70. 